\title{
CONTRIBUTION OF SOIL ATTRIBUTES AND MORPHOLOGICAL VARIABLES TO YIELD OF IRRIGATED GARLIC
}

\author{
Job T. de Oliveira ${ }^{1 *}$, Rubens A. de Oliveira ${ }^{2}$, Marconi R. Furtado Junior ${ }^{2}$
}

${ }^{1 *}$ Corresponding author. Universidade Federal do Mato Grosso do Sul (UFMS), Câmpus de Chapadão do Sul/ Mato Grosso do Sul - MS, Brazil. E-mail: job.oliveira@hotmail.com | ORCID ID: https://orcid.org/ 0000-0001-9046-0382

\section{KEYWORDS}

Allium sativum L., path analysis, precision irrigation, precision agriculture.

\begin{abstract}
This study aimed to investigate relationships between the soil attributes that most affect garlic yield, which can be useful to choose a new area for the growing of this vegetable. We also aimed to study the effects of irrigation deficit at bulb formation stage (cloves) on final garlic quality and yield. The variables evaluated were garlic yield, irrigation, nitrogen, lateral shoot growing, plant water potential, bulb volume, leaf area index, soil electrical conductivity, soil mechanical resistance to penetration, and volumetric soil moisture content. Initially, the Pearson's correlation was estimated for the phenological indexes, and a correlation network was used to graphically express the results and to correct multicollinearity between variables. A track analysis was performed considering yield as the main dependent variable. The analyses showed that, of the primary garlic yield components, bulb volume is the phenological index with the greatest potential for selection and identification of garlic production. Moreover, soil resistance to penetration impaired garlic yield. Finally, irrigation deficit at clove formation stage has a negative relation with lateral shoot growing and bulb volume.
\end{abstract}

\section{INTRODUCTION}

Garlic (Allium sativum L.) is a bulbous plant grown worldwide for culinary and medicinal purposes. Garlic bulbs are rich sources of carbohydrates, proteins, phenols, and antioxidants. Annual global garlic production in 2015/16 was 27 million tons grown in approximately 1.5 million hectares in several countries under different climates (Faostat, 2018).

Water is a factor that most often affects garlic development, production, and quality. In the soil, water deficiency mainly compromises plant development and bulb yield, while its excess impairs bulb quality and conservation (Costa et al., 1993).

Oliveira et al., (2019), citing Carvalho et al., (2006), affirmed that some soil physical factors are especially important when assessing crop response to a specific management strategy, including soil water content and mechanical impediments to root development. Thus, understanding the changes in soil attributes can help improve agricultural productivity.
Quantifying and interpreting the magnitude of a correlation between two variables could give rise to misunderstandings for selection purposes, as high estimates can result from the effect of a third variable on those, or of a set of variables (Cruz et al., 2012). When it is desired to increase crop production through selection of primary and/or secondary components, a correlation study does not indicate the relative importance of direct and indirect effects of such components. Therefore, the truthfulness of the cause-effect relationship cannot be verified.

Path analysis has been used by many authors in several crops with economic importance, such as cotton (Farias et al., 2016), sorghum (Silva et al., 2017a), sugarcane (Silva et al., 2017b), soybeans (Teodoro et al., 2015), beans (Oliveira et al., 2018), and garlic (Oliveira et al., 2020). This study aimed to investigate relationships between the soil attributes that most affect garlic yield, which can be useful to choose a new area for the growing of this vegetable. We also aimed to study the effects of irrigation deficit at bulb formation stage (cloves) on final garlic quality and yield.

\footnotetext{
${ }^{2}$ Universidade Federal de Viçosa (UFV)/ Viçosa - MG, Brazil.
} 


\section{MATERIAL AND METHODS}

The study was carried out in the Irrigation and Drainage Area of the Federal University of Viçosa, in Viçosa city, Minas Gerais State, Brazil. The soil on which experimental grids were installed is classified according to the Brazilian System of Soil Classification (Embrapa, 2018) as a Red-Yellow Latosol with a sandy-clayey texture. Table 1 shows the results of physical and chemical analyses.

TABLE 1. Physical and chemical properties of the Red-Yellow Latosol of the experimental area.

\begin{tabular}{|c|c|c|c|c|c|c|c|c|c|c|c|c|c|c|}
\hline \multirow[t]{2}{*}{ Layer } & \multicolumn{3}{|c|}{ Composition } & \multicolumn{11}{|c|}{ Chemical analysis } \\
\hline & $\mathrm{Sd}$ & $\mathrm{St}$ & $\mathrm{Cy}$ & $\mathrm{pH}$ & $\mathrm{P}$ & $\mathrm{K}^{+}$ & O.M. & $\mathrm{Ca}^{+2}$ & $\mathrm{Mg}^{+2}$ & $\mathrm{H}^{+}+\mathrm{Al}^{+3}$ & $\mathrm{Al}^{+3}$ & SB & CEC & $\overline{B S}$ AS \\
\hline $\mathrm{m}$ & ---- & $\%$ & ---- & $\mathrm{H}_{2} \mathrm{O}$ & $-\mathrm{mg}$ & $\mathrm{dm}^{-3}-$ & dag $\mathrm{kg}^{-1}$ & & ------- & $-\mathrm{cmol}_{\mathrm{c}} \mathrm{d}$ & 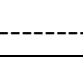 & 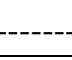 & -- & --- \% --- \\
\hline $0-0.20$ & 46.0 & 15.0 & 39.0 & 6.0 & 21.2 & 135.0 & 2.2 & 2.3 & 1.0 & 2.5 & 0.0 & 3.7 & 6.1 & $60.0 \quad 0.0$ \\
\hline
\end{tabular}

Sd - Sand; St - Silt; Cy - Clay; OM - Organic matter; SB - Sum of bases; CEC - Cation exchange capacity; BS - Base saturation; AS - Al saturation.

The area was prepared and planted with garlic between May 1st and 7th, 2018. As can be seen in Figure 1, the spacing between double rows was $0.40 \mathrm{~m}$ and $0.10 \mathrm{~m}$ between rows within double-rows.

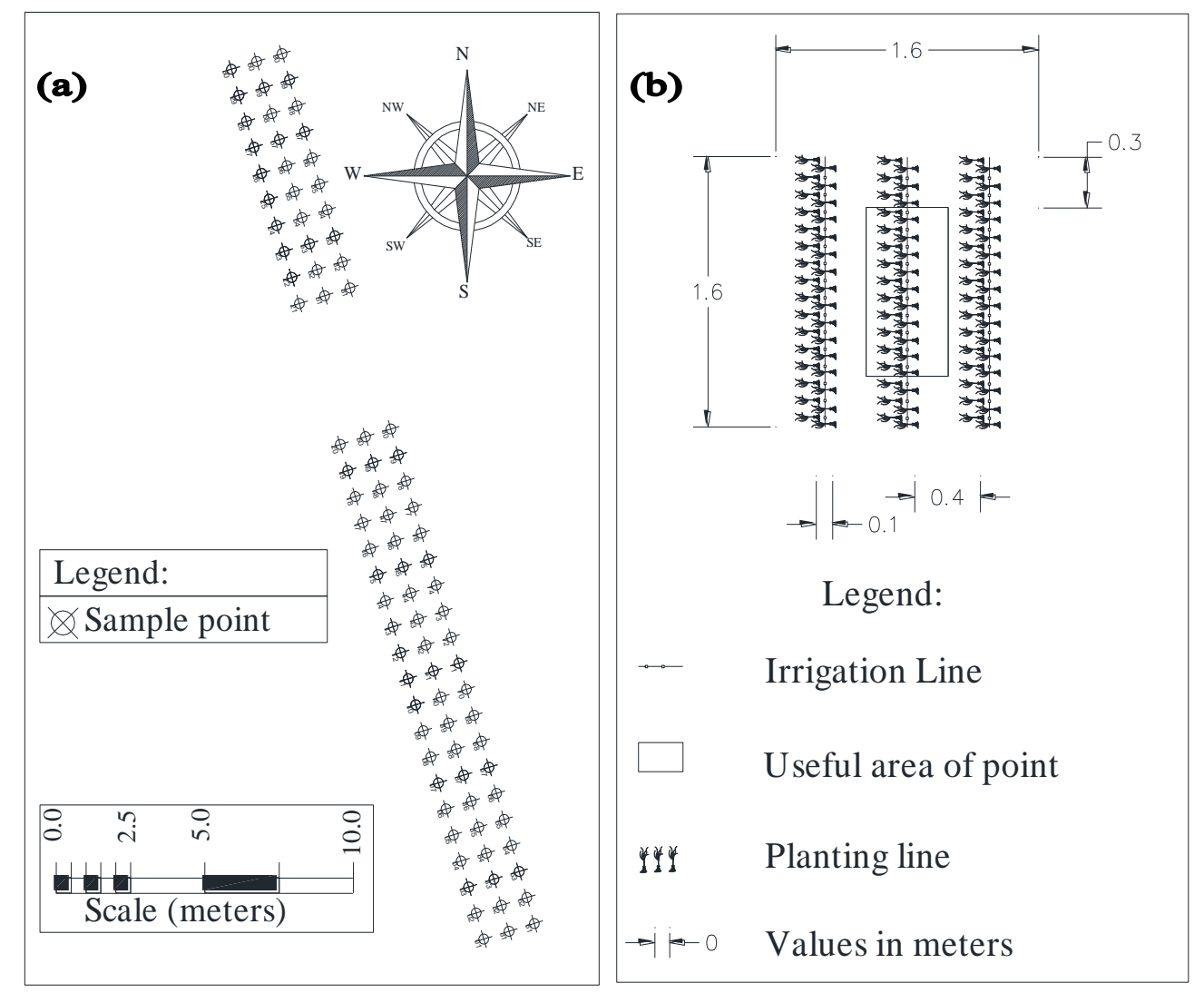

FIGURE 1. (a) Sampling grid and detailing of sampling performed in the Irrigation and Drainage Area of the Federal University of Viçosa, in Viçosa, Minas Gerais, Brazil, (b) sketch of the planting seedbed representing a sampling point.

The $\mathrm{x}$ and $\mathrm{y}$ directions of the Cartesian coordinate system were defined, and the experimental grid was demarcated near the end of the garlic cycle, that is, in midSeptember 2018. The grids were spaced $1.60 \mathrm{~m}$ apart. Each experimental grid was composed of three transects of 48.00 $\mathrm{m} \times 1.60 \mathrm{~m}$. The transects were spaced $1.60 \mathrm{~m}$ apart and had 90 square sample points of $1.60 \mathrm{~m} \mathrm{x} 1.60 \mathrm{~m}$ (Figure 1).

The plant variables studied here were measured individually in plants within the useful area of the sampling point, which was composed of 1 double row with $1.00 \mathrm{~m}$ in length, containing 20 plants. The laboratory stage of analysis was carried out between October and November 2018.

The following agronomic traits were measured:

- Irrigation water deficit (IRR) during clove formation was determined by measuring the amount of water applied over the crop cycle and expressed in $\mathrm{mm}$.
Crop water requirement was monitored by an Irrigameter;

- Nitrogen deficient application (NI) during clove formation was determined by measuring the amount of nitrogen applied during the entire crop cycle and expressed in $\mathrm{kg}$;

- Lateral shoot growing (LSG) was determined as the percentage of plants with lateral shoot growing at each sampling point;

- Plant water potential (WPA) was obtained using a Scholander pressure bomb, model SEC3005H07G4P40. One garlic leaf was cut and inserted into a chamber with a salient tip relative to the support. A pressure was applied inside the chamber until exceeding plant tissue inner tension, and xylem 
sap began to flow from the cut region of the sample. WPA was then read directly from the manometer and expressed in $\mathrm{kPa}$, at 86 days after planting.

- WPB was also determined six hours after irrigation depth application, at 87 days after planting;

- $\quad$ Bulb volume (BV) was calculated by [eq. (1)] and expressed in $\mathrm{cm}^{3}$.

$\mathrm{BV}=4 \pi \frac{(\mathrm{BD})(\mathrm{BL})^{2}}{3}$

$\mathrm{BD}=$ bulb diameter, in $\mathrm{cm}$, and

$\mathrm{BL}=$ bulb length, in $\mathrm{cm}$.

- Leaf area index (LAI) was obtained using an electronic device (PAR/LAI Ceptometer model CP 80) on the day of harvest;

- Soil electrical conductivity (EC) was measured with the aid of the Electrical Resistivity LandMapper, model ERM-02. This device measures electrical resistivity in the surface layer of the 0 to $0.40 \mathrm{~m}$ depth, using a four-electrode probe. The measurements were expressed in $\mathrm{dS} \mathrm{m}^{-1}$ and carried out one day after harvest (September 14th, 2018);

- Mechanical resistance to penetration (RP1) was obtained in the $0.0-0.10 \mathrm{~m}$ depth layer;

- Mechanical resistance to penetration (RP2) was obtained in the $0.10-0.20 \mathrm{~m}$ depth layer;

- Mechanical resistance to penetration (RP3) was obtained in the $0.20-0.30 \mathrm{~m}$ depth layer;

- Mechanical resistance to penetration (RP4) was obtained in the $0.30-0.40 \mathrm{~m}$ depth layer;

- Mechanical resistance to penetration (MRP) which refers to the mean penetration resistance in the entire depth from 0 to $0.40 \mathrm{~m}$. Resistances were obtained using a Falker PenetroLOG-PLG 1020 digital penetrometer, configured to record readings every 5 $\mathrm{mm}$, and constant penetration speed with the unit in $\mathrm{kPa}$;
- Volumetric soil moisture (VSM), in $\mathrm{kg} \mathrm{kg}^{-1}$, was measured using a soil moisture probe manufactured by Falker, equipment model HidroFarm, with a measuring sensor HFM1010 length of $0.20 \mathrm{~m}$, with humidity results expressed in $\%$. The measurements were made 96 days after planting and at the end of clove differentiation period;

- Garlic yield (GY) was determined by weighing the mass of bulbs and expressed in $\mathrm{kg} \mathrm{ha}^{-1}$.

The functional relationships between correlation estimates and between traces were graphically expressed by a correlation network, in which proximity between nodes (traces) was proportional to the absolute value between their correlation. The thickness of the edges was controlled by applying a cut-off value of 0.50 , which meant that only $\mid$ rij $\mid \geq 0.50$ had the margins highlighted. Finally, the positive correlations were represented in green and the negative ones in red.

Then, the correlations were unfolded into direct and indirect effects of the 14 agronomic traits on garlic yield (GY), using a path analysis as described by Cruz et al., (2012). These authors stated that ignoring multicollinearity effects can lead to harmful results. In this sense, the degree of multicollinearity of the matrix $X^{\prime} X$ was established based on its number of condition (NC), which is the relation between the major and minor eigenvalues of the matrix (Montgomery et al., 2012). If NC > 1000, multicollinearity is severe; if $100 \leq \mathrm{NC} \leq 1000$, multicollinearity is moderate to strong; and $\mathrm{NC}<100$, multicollinearity is weak and does not represent a problem for the analysis.

Figure 2 shows a causal chain diagram showing the relationship of the morphological traces of garlic yield (GY) with the other primary components in the path analysis performed. All the statistical analyses were performed with the software Genes (Cruz, 2013). 


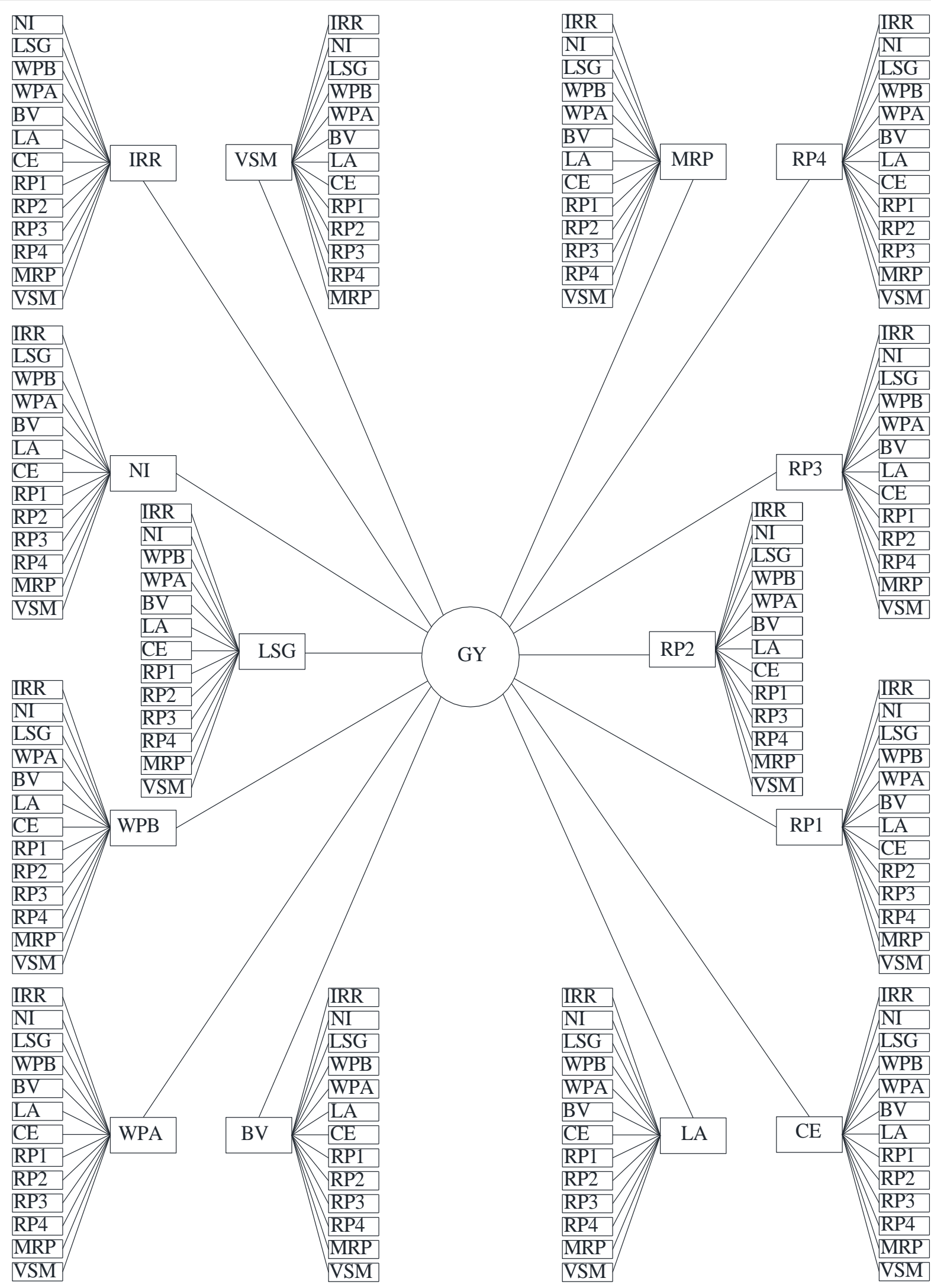

FIGURE 2. Causal chain diagram showing the relationship of the morphological traces of garlic yield (GY) with the other primary components in the path analysis performed.

\section{RESULTS AND DISCUSSION}

Figure 3 expresses the network of Pearson's correlations among morphological variables. The efficiency of such innovative technique to relate many variables has already been highlighted in the literature by Silva et al. (2017a, b), Oliveira et al., (2018), and Oliveira et al., (2019). 


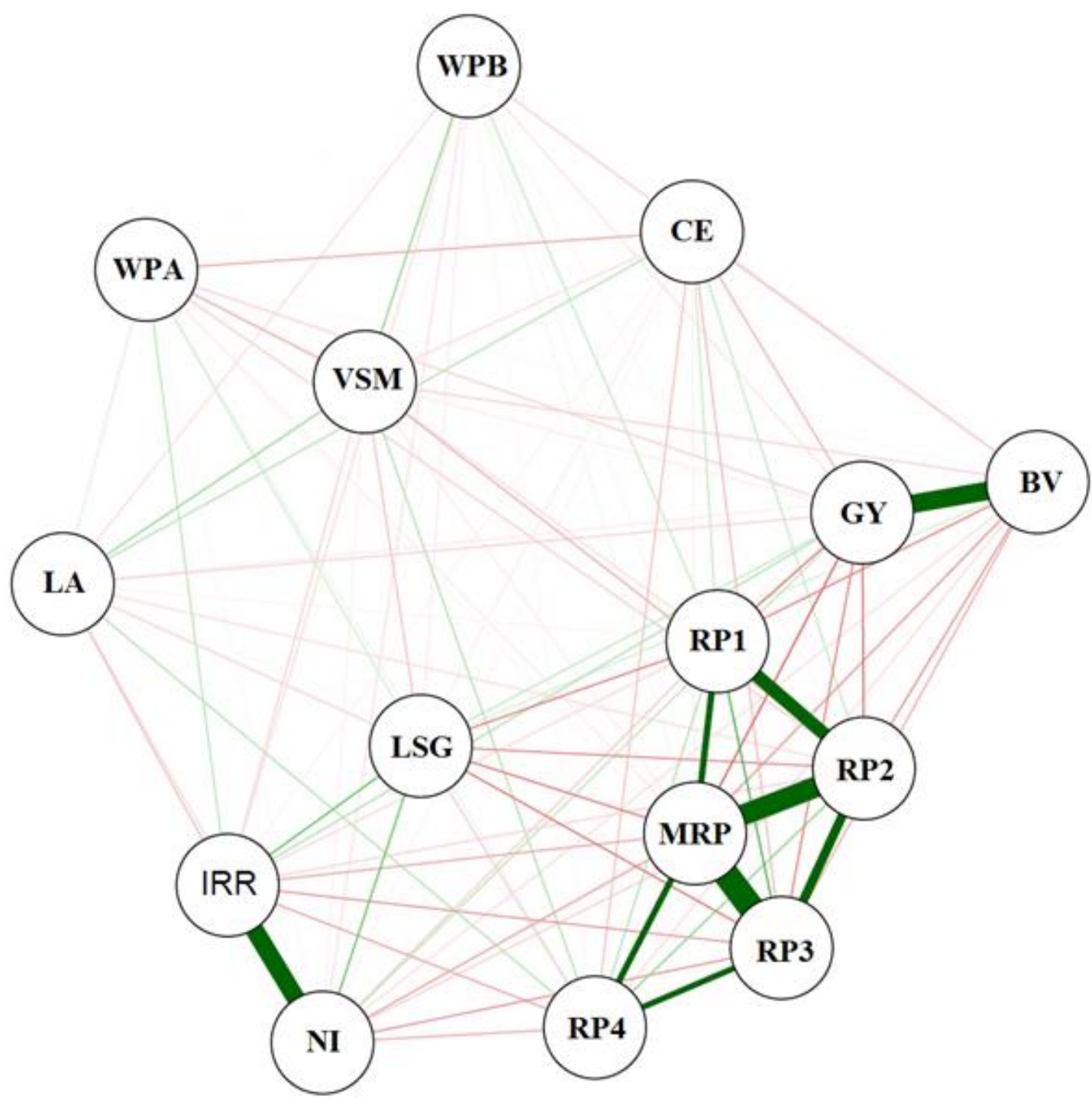

FIGURE 3. Correlation network of the crop traits: garlic yield (GY) with its primary components, irrigation (IRR), nitrogen (NI), lateral shoot growing (LSG), plant water potential (WPA and WPB), bulb volume (BV), leaf area index (LAI), soil electrical conductivity (CE), mechanical resistance to penetration (RP1, RP2, RP3, RP4, and MRP), and volumetric soil moisture (VSM).

Correlation estimates ranged from -0.3487 to 0.9300. There were high and positive correlations between the variables: RP1 x MRP; RP2 x MRP; RP3 x MRP, and RP4 x MRP. Studying the relationships with penetration resistance, Galindo et al., (2018) and Oliveira et al., (2019) also found high and positive correlations between the same variables. These variables also showed high negative correlations with garlic yield (GY). Similar results were obtained in other studies involving resistance to penetration and crop yields, such as Souza Lima et al., (2017) studying eucalyptus, and Oliveira et al., (2019) studying beans.

By analyzing the effects of negative correlations, the relationship between soil resistance to penetration and bulb volume must be highlighted (RP1 x BV, RP2 x BV, RP3 x $\mathrm{BV}, \mathrm{RP} 4 \mathrm{x} \mathrm{BV}$, and MRP $\mathrm{x} \mathrm{BV})$, which showed the following values: $r=-0.2033, r=-0.1798, r=-0.1317, r=-$ 0.0522 , and $\mathrm{r}=-0.1686$, respectively.

A value of $\mathrm{K}$ equals to 0.05 was used for estimation of direct effects (Figure 4) since it was the lowest to allow stabilization of such effects when variables presented multicollinearity. Thus, in the presence of multicollinearity, all variables evaluated in the path analysis can be included, but a constant $(\mathrm{k}=0.05)$ must be added to the diagonal of correlation matrix to solve this problem. The method used by Oliveira et al., 2020 for a garlic trail analysis study. 


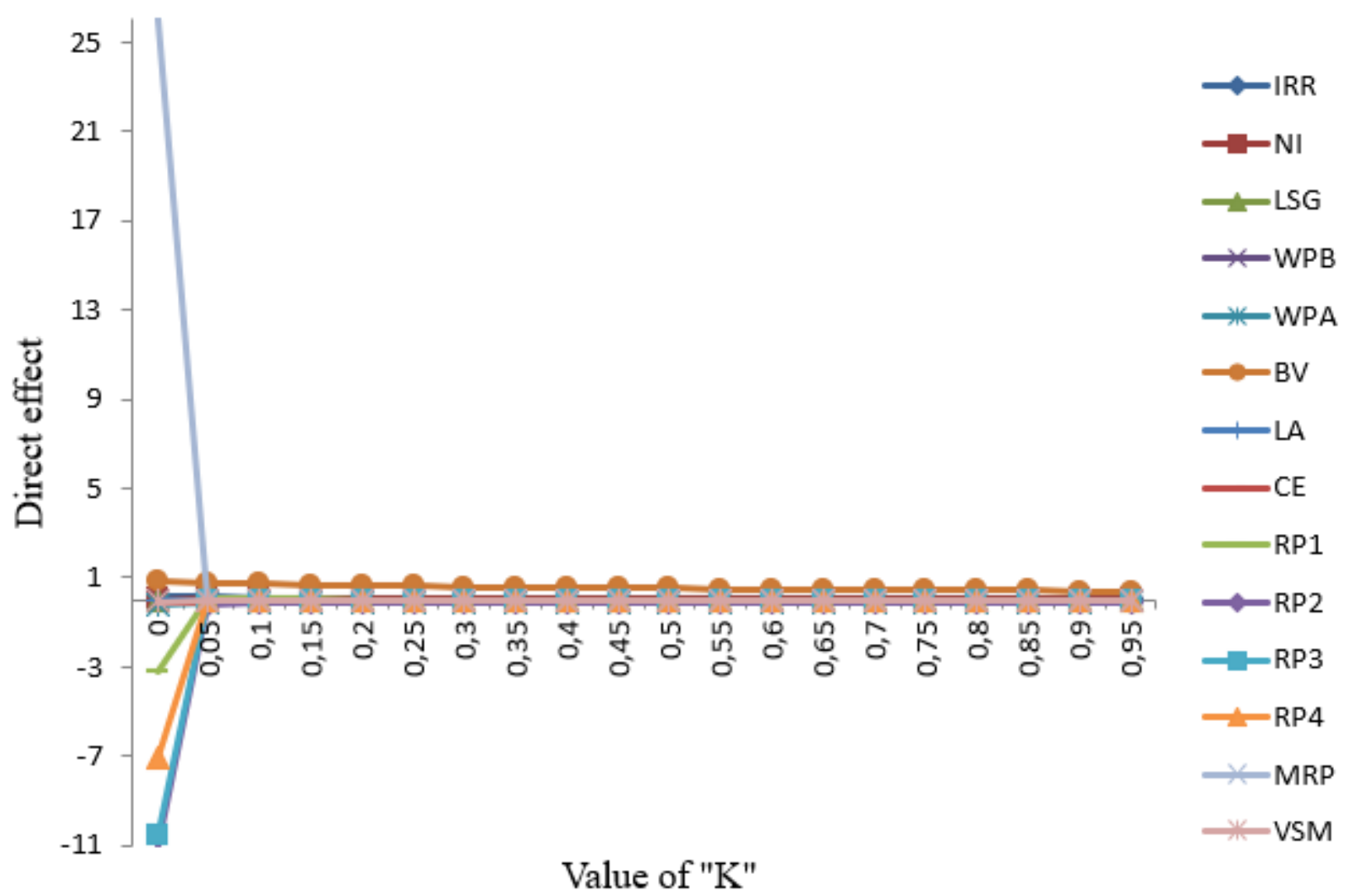

FIGURE 4. Direct effect according to the $\mathrm{k}$ value used for trail analysis in which the main dependent variable is garlic yield (GY).

Figure 5 shows the results of this study, wherein garlic yield (GY) is in the center of the graph. Bulb volume had the highest positive direct effect $(\mathrm{VB})(\mathrm{R} 2=0.7648)$, while soil resistance to penetration (RP2) had the highest negative direct effect $(\mathrm{R} 2=-0.1765)$. For a variable to have a cause-and-effect relationship with more productive plants, it is necessary to have a high direct effect in the same direction as its correlation with production. Thus, for garlic, bulb volume is the most suitable for direct selection of more productive plants, as it has a cause-and-effect relationship with the productivity of this vegetable. When performing a path analysis for garlic, Rezende \& Silva (2015) concluded that bulb diameter and length were strongly correlated $(r>$
0.8 ) with garlic yield. It is worth mentioning that these two variables are directly correlated with bulb volume as well.

We obtained a determination coefficient of 0.7422 , which in turn can be implemented to improve and enhance the growing of such important vegetable through irrigation management studies to minimize water use, thus preserving water resources. This result suggests that the variables evaluated explained much of the garlic yield (main dependent variable). Determination coefficients above 0.70 are considered high. Authors such as Silva et al., 2017b, Teodoro et al., 2015, Oliveira et al., 2018, and Oliveira et al., 2020 have also found coefficients of determination higher than 0.70 . 


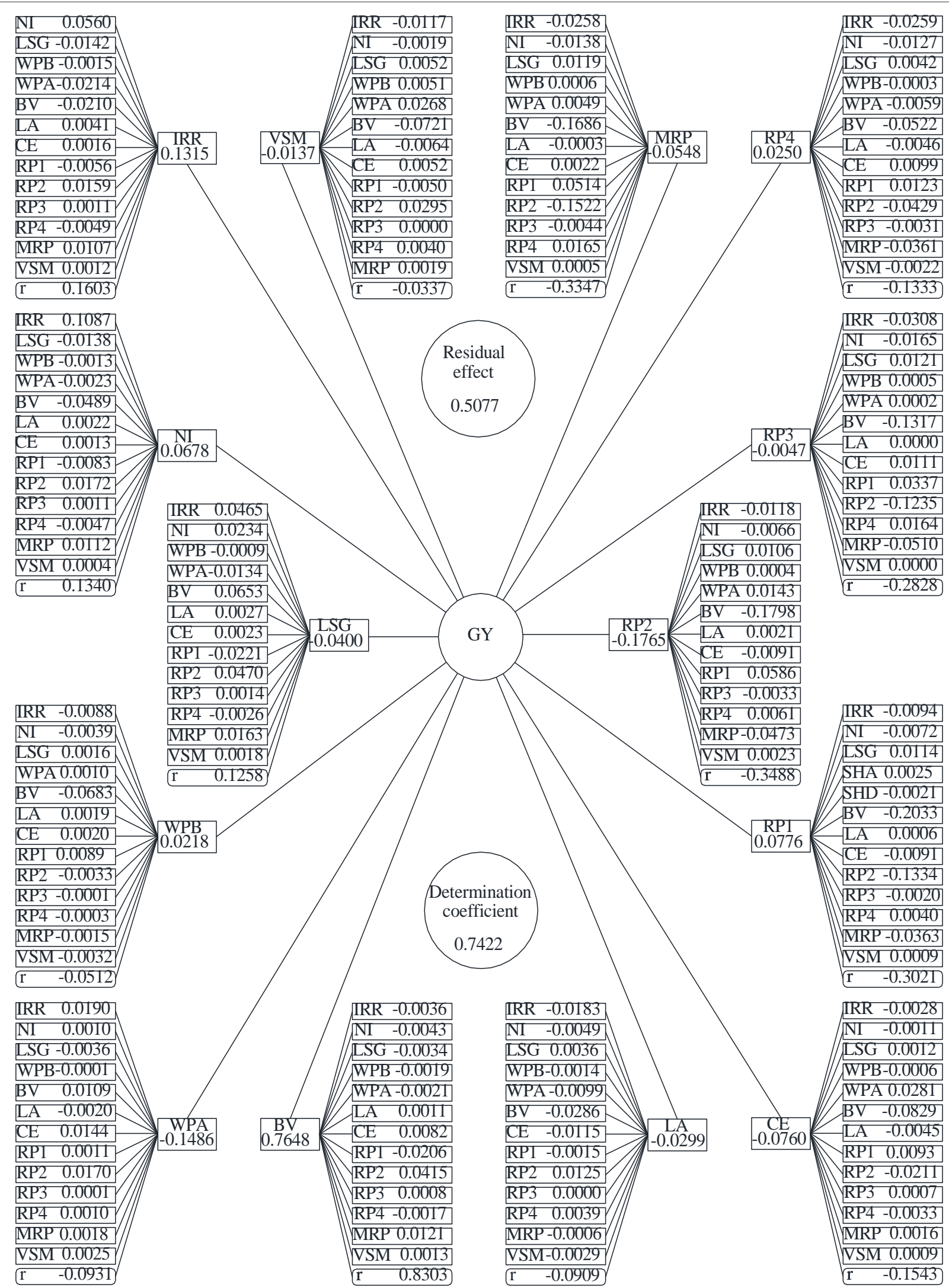

FIGURE 5. Results of path analysis between morphological traces: garlic yield (GY) with its primary components, irrigation (IRR), nitrogen (NI), lateral shoot growing (LSG), water potential of plant (WPA and WPB), bulb volume (BV), leaf area index (LAI), soil electrical conductivity (CE), mechanical resistance to penetration (RP1, RP2, RP3, RP4 and MRP), and volumetric soil moisture (VSM). 


\section{CONCLUSIONS}

Bulb volume is the highest potential phenological index for selection and identification of garlic yield.

Soil resistance to penetration impaired garlic yield, thus this feature must be considered before crop implantation in a new area.

Irrigation deficit at clove formation stage had a negative relationship with lateral shoot growing and bulb volume.

\section{ACKNOWLEDGMENTS}

This study was financed in part by the Coordenação de Aperfeiçoamento de Pessoal de Nível Superior - Brazil (CAPES) - Finance Code 001.

This work was carried out with support from $\mathrm{CNPq}$, Conselho Nacional de Desenvolvimento Científico e Tecnológico - Brazil. 141231/2019-0.

\section{REFERENCES}

Carvalho GJ, Carvalho MP, Freddi OS, Martins MV (2006) Correlação da produtividade do feijão com a resistência à penetração do solo sob plantio direto. Revista Brasileira de Engenharia Agrícola Ambiental 10(3): 765771 . DOI: https://dx.doi.org/10.1590/S141543662006000300033

Costa TMP, Souza RJ, Silva AM (1993) Efeitos de diferentes lâminas de água e doses de nitrogênio sobre a cultura do alho (Allium Sativum L). Ciência e Prática 17(3): 239-246.

Cruz CD, Carneiro PCS, Regazzi AJ (2012) Modelos biométricos aplicados ao melhoramento genético. Viçosa, Editora UFV, 3 ed.

Cruz CD (2013) Genes: A Software Package for Analysis in experimental statistics and quantitative genetics. Acta Scientiarum: Agronomy, 35: 271-276. DOI: https://doi.org/10.4025/actasciagron.v35i3.21251

EMBRAPA - Empresa Brasileira de Pesquisa Agropecuária (2018) Sistema brasileiro de classificação de solos. Embrapa, 5 ed rev ampl.

Farias FJC, Carvalho LP, Silva Filho JL, Teodoro PE (2016) Correlations and path analysis among agronomic and technological traits of upland cotton. Genetics and Molecular Research Journal 15(3). DOI: http://dx.doi.org/10.4238/gmr.15038239

Faostat. Statistics Database. Available: http://www.fao.org/faostat/en/\#home. Accessed Apr, 2020.
Galindo FS, Montanari R, Martins MM, Meirelles FC, Ludkiewicz MG, Silva YDF, Modenese VDS (2018) Specific management areas as a function of dendrometric properties of eucalyptus and physical-chemical attributes in an oxisol. Journal of Agricultural Science 10(5): 34. DOI: https://doi.org/10.5539/jas.v10n5p34

Montgomery DC, Peck EA, Vining GG (2012) Introduction to linear regression analysis. New York, Wiley, 5 ed. 672p.

Oliveira JT, Ribeiro IS, Roque CG, Montanari R, Gava R, Teodoro PE (2018) Contribution of morphological traits for grain yield in common bean. Bioscience Journal 34 (2). DOI: https://doi.org/10.14393/BJ-v34n2a2018-39701

Oliveira JT, Roque CG, Oliveira RA, Montanari R, Guimarães CM, Araujo ED (2019) Inter-relationships of resistance to penetration, moisture and soil organic matter with irrigated bean yield in Mato Grosso do Sul, Brazil. Journal of Agricultural Science 10(9). DOI: https://doi.org/10.9734/jeai/2019/v31i330075

Oliveira JT, Oliveira RA, Cunha, FF, Ribeiro IS, Oliveira, LAA, Teodoro PE (2020) Contribution of morphological variables in garlic bulb yield. Hortscience 55(6): 896-897. DOI: https://doi.org/10.21273/HORTSCI14996-20

Rezende BR, Silva AR (2015) Análise de trilha da produtividade de alho com inclusão de variável multicategórica. Multi-Science Journal 1(3):13-16. DOI: http://dx.doi.org/10.33837/msj.v1i3.93

Silva KJ, Teodoro PE, Menezes CB, Julio MPM, Souza VF, Silva MJ, Pimentel LD, Borem A (2017a)

Contribution of morph agronomic traits to grain yield and earliness in grain sorghum. Genetics and Molecular Research Journal 16(2). DOI:

http://dx.doi.org/10.4238/gmr16029649

Silva LA, Teodoro PE, Peixoto LA, Assis C, Gasparini K, Barbosa MHPB, Bhering LL (2017b) Selecting sugarcane genotypes by the selection index reveals high gain for technological quality traits. Genetics and Molecular Research Journal 16(2). DOI: http://dx.doi.org/10.4238/gmr16029678

Souza Lima E, Montanari R, Lovera LH, Teixeira Filho MCM, Silva VE, Rocha Lima CG (2017) Spatial variability of eucalyptus and physical attributes of soil fertilized with lime mud and mineral fertilizer. Brazilian Journal of Agriculture - revista de agricultura 92(2): 132146. DOI: https://doi.org/10.37856/bja.v92i2.3170

Teodoro PE, Ribeiro LP, Correa CCG, Junior RAAL, Zanuncio A, Capristo DP, Torres FE (2015) Path analysis in soybean genotypes as function of growth habit. Bioscience Journal 31: 794-799. DOI: https://doi.org/10.14393/BJ-v31n1a2015-26094 